\title{
Sustainable Development Strategies For The Hinterland KTM Telang, Banyuasin District, Indonesia
}

\author{
Zulkifli Idrus ${ }^{1 *}$, Andy Mulyana ${ }^{2}$, M. Edi Armanto ${ }^{2}$, Didik Susetyo ${ }^{3}$, Nurhayati Damiri ${ }^{1}$, \\ Iwan A. Ratmoko ${ }^{1}$,Syuhada A. Umar ${ }^{1}$, and Nuryamsasni ${ }^{1}$ \\ ${ }^{1}$ Study Program of Science Environment, Sriwijaya University, South Sumatra, Indonesia \\ ${ }^{2}$ Faculty of Agriculture, Sriwijaya University, South Sumatra, Indonesia \\ ${ }^{3}$ Faculty of Economy, Sriwijaya University, South Sumatra, Indonesia
}

\begin{abstract}
The Development of Independent Integrated City (Kota Terpadu Mandiri/KTM) Telang has been going on for 10 years and has succeeded in increasing economic growth in the KTM Telang and the surrounding area. Economic growth at the KTM Center has not been fully felt by the people of Hinterland. The lack of linkages between the city center and the region behind it is the reason for researchers to formulate a sustainable development strategy for the Telang hinterland. The study was conducted in the KTM Telang Area which included three sub-districts, namely Tanjung Lago Sub-District, Muara Telang, and Sumber Marga Telang. Primary data collection techniques are done through in-depth interviews with respondents selected by purposive sampling. The data analysis technique used in this study is the AHP (Analytical Hierarchy Product) method. Based on the results of interviews processed by the AHP method the development of the KTM Telang hinterland area is carried out by taking into account aspects sorted according to priority interests, among others through increasing power capacity (1.00), developing market networks (0.59), developing irrigation networks (0.41). Furthermore, social aspects are carried out through enhancing the ability of human resources (0.23), cooperation (0.17), improving communication ( 0.15$)$, strengthening institutions and associations $(0.07){ }^{1}$
\end{abstract}

Keywords: Sustainable Development, KTM Telang, Hinterland Area

\section{Introduction}

Economic development in Indonesia cannot be separated from the role of the agricultural sector. As an agricultural country, approximately $40 \%$ of Indonesia's population depend on agriculture [1]. Strong and sustainable regional economic development is an effective

*Corresponding authors : ir.zulkifliidrus@gmail.com 
collaboration between the use of available resources, the community, and the government [2]. Sustainable development is a multidimensional relevance to the ever-increasing social life. This aims to balance the socio-economic and environmental impacts of the existing development. The concept of sustainable development shows the simultaneous harmonization or realization of various aspects [3].

The development approach that emphasizes macroeconomic growth causes the concentration of investment and resources in cities and urban centers of growth, while the hinterland region experiences excessive drainage of resources [4]. As a critique of government policy that is too focused on promoting economic development in metropolitan areas, there is an introduction of urban-rural 'supra-regional' that seeks to create accountability and solidarity relations between metropolitan areas and rural areas [5]. Urban historians tend to think of rural areas as urban-rural areas, whereas rural historians generally speak of urban dwellers as new groups acting as landlords [6]. Cities and rural areas have a good relationship between economic, social, cultural and political aspects with varying governance arrangements [7]. City centers can effectively encourage the commercialization of agriculture only if they are well connected to the interior [8]. Based on the Master Plan for the Acceleration and Expansion of Indonesian Economic Development (MP3EI) Banyuasin Regency is one part of the economic corridor of South Sumatra, which is a gateway for international trade and a center for downstream industrial areas in South Sumatra Province. Several national and provincial programs have been launched, starting from the construction of seaports, toll roads, double-track railroads, and the construction of Special Economic Zones (KEK).

Banyuasin Regency is a transmigration area in South Sumatra Province. The transmigration program aims to reduce poverty by providing land and employment opportunities for the poor [9]. Since the 1980s, transmigration scheme has been carried out on wetlands and has affected the process of agricultural restructuration, rural industry process, urbanization and economic reforms as well as has led to the decrease of agricultural area [10]. The major development problem is the less utilization of natural resources of Banyuasin, a linkage will be effected by differential capital investment and through implementation of the transmigration policy [11].

Independent Integrated City (KTM) is a program that is designed holistically and comprehensively, which aims to build an urbanized transmigration area, as an acceleration of the development of an independent rural economy. The hinterland area is a rear area that acts as a production center. The linkage between the KTM Telang and its hinterland is following the National Medium-Term Strategic Plan (2010-2014) that one of the strategic issues in local and regional economic development is the weak economic linkages between regions and between production centers and processing and marketing centers. Furthermore, efforts to increase local and regional economic development are the increasing linkages of economic activities between growth centers and production areas (hinterland).

The development of the area around the growth center of KTM Telang is expected to be through a trickle-down effect. However, based on the existing conditions the KTM Telang hinterland community has not fully felt the changes either from the economic, social and environmental aspects as a result of the development of the KTM Telang center, Therefore, the need for planning in the context of the development and development of the TelangKTMinterland area to achieve progress in terms of the economy and social aspects.

In line with the ongoing development in Banyuasin District, researchers are interested in formulating a sustainable hinterland development strategy as a supporter of the economic center at the KTM Telang to reduce disparities in the status of villages in the hinterland region by increasing the synergy of increasing the effectiveness of regional development programs. 


\section{Methodology}

The study was conducted at the KTM Telang in according to the Banyuasin District Regulation No. 22/2008 concerning the Establishment of the KTM Area and the Regent Decree No. 341/2008 dated July 17, 2008, concerning the Determination of the KTM Telang Telang Center Location Mulya Sari Village, Tanjung Lago District, which stipulates that the KTM Telang covers three districts namely Tanjung Lago District, Muara Telang District, and Sumber Marga Telang District. The study was conducted for 6 (six) months from March 2019 to August 2019.
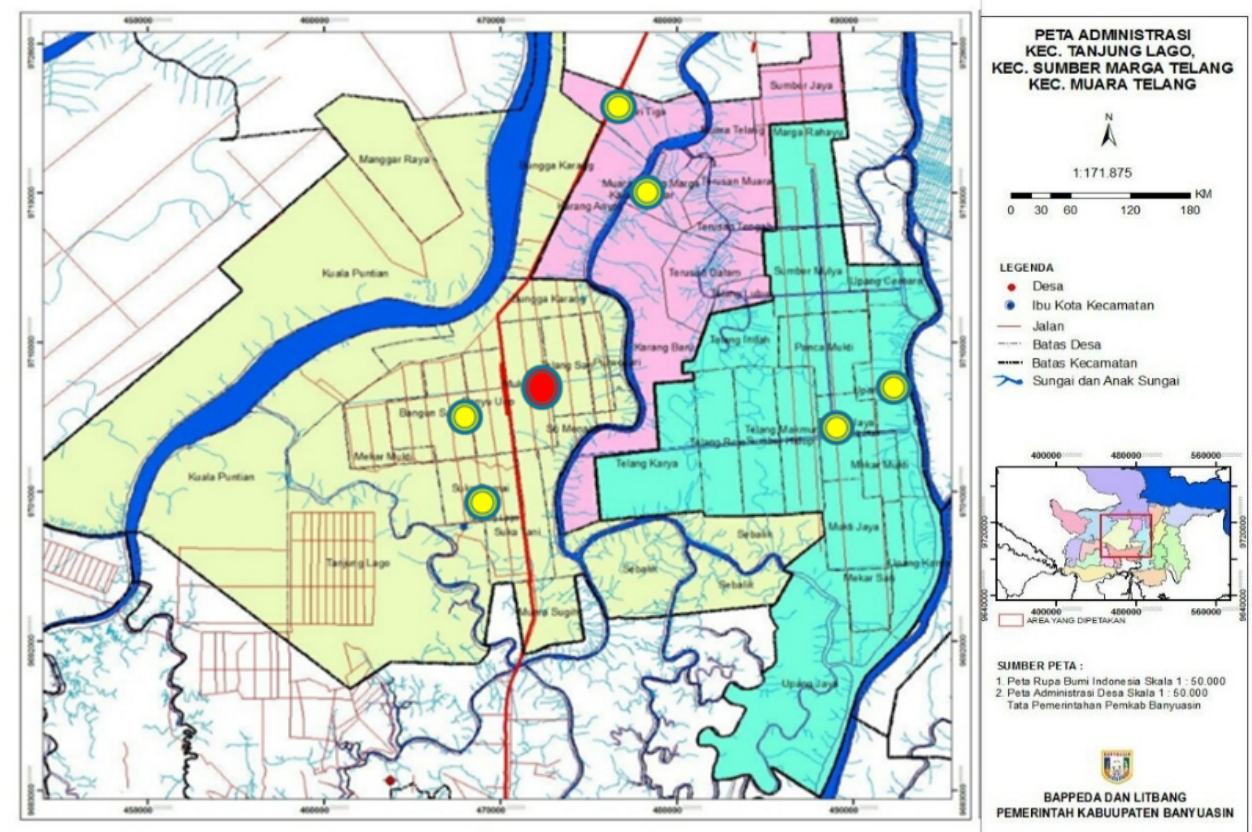

Fig 1. Research Location Map

The sample in this study is the community used as respondents determined using the Purposive Sampling method, which is a method that is done by taking subjects not on strata but based on specific objectives, namely community leaders who play a role in group representation and have lived in the KTM region since before KTM Telang was launched.

The type of data used is primary data obtained from direct observations and surveys in the field and in-depth interviews using questionnaires with community leaders and business actors who directly observe the development of the KTM Telang from time to time.

The data analysis technique used to formulate a sustainable development strategy for the KTM Telang hinterland area is carried out using the AHP analysis or Analytical Hierarchy Process in ArcGIS 10.3 software. AHP technique is widely used in the decision making process for many criteria, planning, allocation of resources, and determining priorities of the strategies owned by players in conflict situations.

In this study, the AHP method is analyzed to determine priority choices based on community perceptions of aspects of infrastructure, social, economic, and environmental development with several variables therein. Each paired variable is given a value in the range 1-9 to determine how important one variable is compared to other variables. 
Table 1. Pairwise Comparison of Research Variables

\begin{tabular}{lll}
\hline \multicolumn{1}{c}{ More Important } & & \multicolumn{1}{c}{ More Important } \\
\hline Electricity Development & Vs & Market \\
Market & Vs & Irrigation \\
Irrigation & Vs & Communication \\
Human Resources Capability & Vs & Association \\
Increased Benefits & Vs & Connectivity \\
Connectivity & Vs & Business Diversification \\
Business Diversification & Vs & Access Bank Services \\
Economic growth & Vs & Living environment \\
Living environment & Vs & Infrastructure development \\
Infrastructure development & Vs & Social aspects \\
\hline
\end{tabular}

\section{Result and Discussion}

The growth of the KTM Telang downtown area is expected to provide a positive breakthrough for the economic growth of the surrounding area or the region behind it (hinterland), through the acculturation of the sector or subsector base as a driving force for the regional economy and economic linkages between regions [12].

Problem Identification
Infrastructure Development at the
KTM Center has no significant
impact on the economic growth of
the hinterland region
There is no influence of activities in
the hinterland on the development
and economic growth at the KTM
center (the amount of leakage and
there is no product added value)
Rivers and canals that used to be a
means of transportation, now
become a barrier/cause of high
costs.




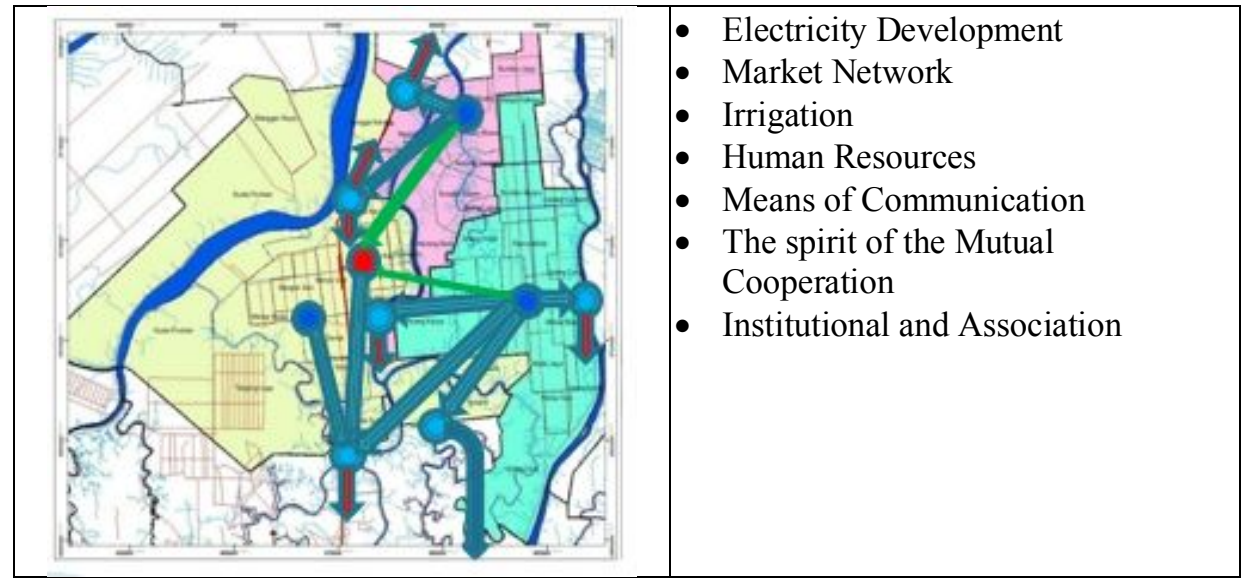

Fig 2. Problem Identification and Development Solution

According to the problems above, the need for a sustainable hinterland area development strategy is carried out from various aspects. To see the direction and priorities of development in KTM Telang can be done using AHP (Analytical Hierarchy Process) analysis.

Table 2. Results of AHP analysis Priority aspects of the development of the Hinterland Region

\begin{tabular}{|c|c|c|c|c|c|}
\hline Graphic & Alternatives & Total & Normal & Ideal & Ranking \\
\hline & Association & 0.0139 & 0.0278 & 0.0740 & 7 \\
\hline & Cooperation & 0.0298 & 0.0597 & 0.1589 & 6 \\
\hline & Irrigation & 0.0785 & 0.1571 & 0.4185 & 3 \\
\hline & $\begin{array}{l}\text { Human Resources } \\
\text { Capability }\end{array}$ & 0.0446 & 0.0892 & 0.2376 & 4 \\
\hline & Communication & 0.0329 & 0.0658 & 0.1752 & 5 \\
\hline & Electricity & 0.1877 & 0.3754 & 1.0000 & 1 \\
\hline & Market & 0.1125 & 0.2251 & 0.5996 & 2 \\
\hline
\end{tabular}

Source: Data Analysis (2019)

Based on the results of the analysis by the AHP method to see the development priorities that support the KTM Telang so that it becomes a new center of economic growth with minimal environmental impact is as follows: 
1) Increase power and decrease the frequency of blackouts

AHP analysis results show that electricity development has a priority value of 1.00 which is the highest value from other aspects. Along with the increasing population in the KTM Telang Area, the need for electricity is also increasing. Given the importance of electricity as one of the most vital needs for daily needs and to meet the needs of people's lives. Power outage cases that often occur at KTM Telang become one of the disturbances and obstacles in carrying out activities, especially the power outages that are always accompanied by the loss of signal on the cellphone. Based on observations and interviews in the field, Siti Rohaya, one of the residents in Tanjung Lago Subdistrict, said that lights often occur where for one week it can be 3-4 times and within 1 day the electricity can be extinguished for 12 hours a day. The number of complaints from the public regarding power outages has become an incentive for the government to place electricity in the development priorities at the KTM Telang. The direction of electricity development by increasing electricity power and capacity is adjusted to the needs of society and industry. Furthermore, by minimizing the occurrence of interruptions and improving the quality of service to the public.

\section{2) Market development (marketing network) including virtual markets, which are online-} based

The market is a major forum for buying and selling transactions between producers and consumers. The AHP analysis results from the priority value for market development is 0.59 , the second-highest after electricity development. The physical form of the market is already widely available both in the KTM Center or the KTM parent market and in the KTM Telang Hinterland area. But the facts on the ground show that the condition of the KTM Telang wholesale market is still quiet, both from the number of sellers and buyers. Increasing the market network both offline and online is one of the development priorities in the KTM Telang, considering that the KTM Telang area is an agricultural sector producing regions, especially rice commodities, so a broad market network will facilitate the movement of goods and services that will have an impact on increasing the income of farmers in the KTM Telang. The existence of UKM-Mart as one of the marketing platforms for several products such as rice lines, various processed chips, and other products made by KTM Telang is an effort to provide markets, but these products are only known by the KTM Telang community and the Banyuasin community. Therefore, the expansion of the virtual market network needs to be done to introduce the unique products of KTM Telang to become better known not only to the Banyuasin community but also to the wider South Sumatra.

\section{3) Repair of irrigation channels}

Banyuasin Regency is an agricultural area in South Sumatra. One of the biggest productions in the KTM Telang Area. The agricultural sector is inseparable from the requirements of sufficient water for farming needs. Based on the results of the analysis, the AHP priority value for repairing irrigation channels is 0.41 . In general agriculture in the KTM Telang Region is a type of tidal agriculture while the air source comes from tidal air. However, a problem arises in the compilation of drought, which is why it is necessary to increase the irrigation network for the need of air to the farmers' fields

4) Increasing the ability of Human Resources (HR) to complement the improvement in the quality and quantity of $H R$

The level of education is one of the aspects used to see the quality of Human Resources. This aspect is the fourth priority based on the results of the AHP analysis with a value of 0.23 . Education is also one of the factors that influence the implementation and 
success of a program because of the level of community understanding of the educational aspects. In addition to skill level education or skills is an important aspect of determining the quality of human resources. Based on the results of field studies on the level of the community in processing raw materials or diversifying food is still relatively low. KTM in Mulya Sari Village, Tanjung Lago Subdistrict, the level of ability of the community is already quite high, such as UKM Mart which accommodates and sells farmer's products such as tempeh chips, bananas, sweet potatoes, and others. Crafts such as cigarette ashtrays, convection, or production houses built by MSMEs are equipped with headscarves, clothing using their branding.

\section{5) Development of communication facilities}

The construction of communication facilities is inseparable from the construction of electricity. Conditions in the field show that for some cellphone operator (Telkomsel) signals, such as Telkomsel and several other signal operators produced are still weak. But the signal will be lost interrupted along with the power outage at KTM Telang. Communication is used for various community needs in the KTM Telang Area which includes knowledge about weather, marketing, commodity flow, prices, banking transactions, and various other uses with various uses depending on needs. The direction of development of communication facilities with the tower upgrade, providers, and the increase in network access power. With the hope that the information system will be more spread among the people. While for the KTM Center by providing free wifi facilities in certain public places. This planning involves coordinated cooperation between the government and private parties providing the parties.

6) Revive the spirit of cooperation

Based on the results of AHP analysis aspects of cooperation to be the sixth priority with a value of 0.15 . Cooperation is an activity that is characteristic of rural communities in Indonesia. The modern era not only changes the physical appearance of an area but also slowly erodes the customs and social habits of the people since long ago. One of the social attitudes that are beginning to experience a crisis today is cooperation and individualist attitudes become more dominant in the values of society. Development planned at KTM Telang will only succeed with the participation and contribution of the community as well as a sense of belonging and helping one another to achieve the desired results following the plans and initial objectives of the government.

\section{7) Strengthening institutions and associations}

Institutions and associations become the last priority in the development and development plan of the KTM Telang with a priority value of 0.07 . Institutions and associations in peasant confusion function as a container that contains regulations to protect farmers. The institutional forms that already exist in KTM Telang such as the Farmers Group (Poktan), the Farmers Group Association (Gapoktan), Village Unit Cooperatives (KUD), and Village Owned Enterprises (BUMDes). Association is closely related to the social life of the community, the importance of the association to strengthen the role of the community in determining policies and decisions to be achieved in a development plan by the government. So with the existence of strong institutions and associations, community participation and contribution are also greater in the process of regional development.

The strategies that can be formulated based on priority aspects of the results of the analysis using the AHP method above in supporting the sustainable development and development of the KTM Telang Hinterland region include: 
a. Electricity Development

The diversity of household industry activities in the KTM Telang Area such as making spinach chips, sweet potato chips, potatoes, and so on requires electricity to support the smooth running of the MSME business. The importance of the role of electricity in supporting the activities of the agricultural product processing industry in the KTM Telang Region. The strategy that the government can undertake to improve electricity development is to increase electricity power and reduce the frequency of power cuts which usually occur in turns in the KTM Telang Area.

b. Market Network Development

Market network development is an important indicator in supporting the marketing of agricultural products in the KTM Telang Area. Agricultural products are products that are generally not durable so we need an appropriate container to accommodate agricultural products. Currently, one of the marketing institutions available at KTM Telang is UKM-Mart that accommodates agricultural products that have been packaged and given price tags to be marketed to consumers. In addition to the availability of marketing institutions, technology support is also important to update market information related to product prices, profit levels, losses, and other information needed.

c. Irrigation Network Development

Water management mainly consists of three important components, such as drainage, irrigation and inundation [13]. The construction of irrigation networks in addition to ensuring water and micro-water systems in farmers' farmland will also support the improvement of the crop index from Ip 200 to Ip 300, especially for rice and corn crops. The construction of irrigation networks also has a connection with the plan for the development of tidal swampland development programs. Where irrigation construction is carried out without damaging the swamp / tidal areas that are appropriate to their function and designation. So that the balance of the ecosystem is maintained. Irrigation networks also play a role in reducing the level of acidity and soil salinity.

\section{d. Improvement of Human Resources Capability}

Steps that can be taken in improving the capacity of farmers' HR are by providing skills training by extension agents or government cooperation institutions such as the establishment of BLK (Job Training Centers). Besides the importance of increasing the interest of young people who have been equipped with skills in agriculture to want to work in the agricultural sector so that the potential of existing natural resources can be managed well and provide benefits to the community of KTM Telang and Banyuasin District.

e. Mutual Cooperation Improvement

Communities in rural areas are known for their cooperation traditions which are still very high when compared to urban communities. This can also be seen in the habits of the KTM Telang people who still choose the tradition of community life in their social life despite differences in religion and customs because the KTM Telang community consists of various tribes. Increasing the cooperation tradition is also expected to be a solution to the problem of employment (Difficulty in getting jobs) so that it will encourage improvements in the economy and a better standard of living. 
f. Improved Communication

The strategic step in the aspect of improving communication is to improve and improve telephone networks to make it easier to find and obtain information access. Access to information that is easy and affordable will make it easier for farmers and the community to run and move the wheels of the economy, especially in agriculture such as market information and technology, and increase the knowledge of the farming community.

g. Institutional and Association Strengthening

The strategy that can be formulated in strengthening institutions and associations is to establish an area management body that is based on shared interests and aims to strengthen the unity and integrity of both the government and the community. The importance of establishing this management body is a forum for coordination between the government, stakeholders, stakeholders, and farmers so that the achievement of common goals in supporting regional development and development is achieved. One tangible form of this strategic step is to make plans for the construction of a sub-district office in the KTM Telang Center, in Mulya Sari Village.

\section{Conclusion}

Based on the results and discussion of the sustainable development of the KTM Telang hinterland region, the following conclusions can be formulated: The sustainable development strategy of the sustainable KTM Telang hinterland area is carried out through infrastructure and social development in the order of priority as follows: Electricity Development, Market Network Development, Irrigation Network Development, Improvement of Human Resources Capability, Mutual Cooperation Improvement, Improved Communication, Institutional and Association Strengthening

The sustainable development of the Hinterland region through infrastructure and social development is carried out with due regard to the geographical conditions of the region and the needs of the community through a coordinated Bottom-Up approach so that a planning program that is right on target and following community needs is obtained. 


\section{References}

1. A. Bashir, D. Susetyo, Suhel, Azwardi. International Journal of Food and Agricultural Economics 6, 4 (2018)

2. D. Satria. Journal of Indonesian Apllied Economics 3, 1 (2009)

3. H. Gervasio and L.S. Silva. Journal Expert Systems with Applications, 39 (2012)

4. Rahayu dan Santoso. Journal of Teknik Pomits 3 (2014)

5. J. Harrison and Growe. European Urban and Regional Studies 21 (2012)

6. T. Soens, E.V. Onacker, and K. Dombrecht. Journal Low Countries Historical 127 (2012)

7. T. Gore. Journal of People, Place \& Policy 1 (2007)

8. R. Nepal, and G.B. Thapa. Journal of Applied Geography 29 (2009)

9. E. Wildayana and M.E. Armanto. Bulgarian Journal of Agricultural Science 24, 2 (2018)

10. E. Wildayana, D. Adriani. and M.E. Armanto. Journal of Environment 2 (2017)

11. M.E. Armanto, R.H. Susanto and E. Wildayana. Sriwijaya Journal of Environment 2, 1 (2017b)

12. B. Wijaya dan H.D. Atmanti. Journal of Dinamika Pembangunan 3, 2 (2006)

13. M.E. Armanto, E. Wildayana, M.S. Imanudin, H. Junedi, M. Zuhdi. Journal of wetlands Environmental Management 5, 2 (2017) 